\title{
Analysis on WeChat-Based Blended Learning in Network Marketing Course
}

\author{
$\underline{\text { https://doi.org/10.3991/ijet.v14i17.11277 }}$ \\ Liang Zhang, Yi Wu, XueSheng Qian, Ping Lv $(\bowtie)$ \\ Guizhou Normal University, Guiyang, China \\ ftygygz@vip.sina.com \\ Xue Zhou \\ University of Chicago, Chicago, United States
}

\begin{abstract}
Blended learning is an information-based teaching method. This method is applied in network marketing course and verifying its teaching effect is a problem worthy of research. By combining blended learning-related theories, student features, and course requirements, a WeChat-based blended learning pattern applicable to network marketing course was proposed in this study. A teaching design of WeChat-based blended learning was created, followed by a teaching experiment. Quantitative analysis was used to verify the teaching results of the experimental and control classes. Results demonstrate that the learning effect of experimental class adopting WeChat-based blended learning is superior to that of the control class adopting traditional teaching method. WeChatbased blended learning lengthens extracurricular learning time, enhances students' learning interest, and increases the opportunity of student-teacher exchange. This study provides references for developing WeChat-based hybrid learning.
\end{abstract}

Keywords - Internet marketing, blended learning, WeChat, teaching

\section{Introduction}

The Internet has become part of people's life, and the Internet economy is the new driving force for socio-economic growth. E-commerce is an important part of the Internet economy, and network marketing is the foundation and precondition for Ecommerce. With deep fusion of Internet and entity economy, Internet business competition is fierce, and enterprises have more urgent demand for network marketing talents. Network marketing course, which is the core course of marketing major, plays a crucial role for students to master e-commerce competency and improve their professional qualities. Rapid e-commerce development in China provides a large quantity of vivid examples and advanced technical support, and this situation helps professional teachers carry out network teaching. Concurrently, the teaching concepts and methods of professional teachers in network marketing must be adapted to changing trends. 
As a teaching pattern combining online learning and traditional classroom methods, blended learning has drawn extensive attention from educators as educational informatization expands. Blended learning has already reached achievements in domestic and foreign teaching practices in middle and primary schools and higher education institutions. The demonstration school construction of national educational reform and development is promoted. Along with it, hardware conditions for carrying out blended learning are satisfied, so blended learning has been increasingly applied to teaching.

As a cross-platform communication tool produced by Tencent, WeChat supports single- and multi-person participation and allows sending voice, picture, video, and text through mobile phone networks. WeChat has abundant functions and enjoys an enormous number of users, with the number of active WeChat users worldwide reaching more than 1 billion. Given the functional abundance and popularity degree of WeChat, a growing number of educators are exploring its application value in education. As a mainstream network social platform, WeChat is one of main battlefields for enterprises to carry out network marketing competition. Thus, network marketing teaching has advantages of combining practices.

Blended learning is introduced into network marketing course teaching. According to the theories of blended learning, the WeChat platform is used to optimize a series of teaching links, such as design, process, and evaluation of network marketing course. Furthermore, WeChat is utilized to study teaching and learning patterns whereby network marketing course teaching is deeply integrated into the Internet. This study applies concepts and methods of blended learning to network marketing course, explores the course's teaching pattern of WeChat-based blended learning, verifies and analyzes practical effects of WeChat-based blended learning in network marketing course, and summarizes ways to use WeChat-based blended learning to improve the teaching effect of the course.

\section{State of Art}

Basic theoretical investigation is the foundation of blended learning research. In 2003, Prof. Zhiting Zhu systematically introduced blended learning in China in his thesis "Blended Learning in Distance Education." At that time, blended learning, translated as "Hun He Xue Xi" in Chinese, was divided into three dimensions, namely, teaching media, learning pattern, and learning content, and the significance of blended learning to distance education in China was discussed [1]. Alfred P. Rovai and Hope M. Jorda used causal comparative design to verify the relationship of team awareness and if blended learning can enable students generate strong team awareness between traditional classroom and blended and completely online learning environment of higher education [2]. Jared M. Carman put forward five major elements of blended design, which are collaboration, site activity, autonomous learning, performance supporting materials, and evaluation [3].

Research on the construction of blended learning resources investigates the organic combination of learning resources and platform construction based on blended learn- 
ing and the effective promotion of the fusion of online and offline learning. Platforms used to investigate blended learning are divided into three types. For platforms developed for blended learning, the representative platform is IndigoCloud (Lanmoyun, a Chinese teaching platform). Hong Wang and Hu Zhang et al. used IndigoCloud class platform to study blended learning [4]. The second type is platform mainly applied to online learning, which can be applied to blended learning if slightly transformed. The representative platform is Moodle. Weihong Kong and Ruili Gao used Moodle opensource software for design and practice of blended learning [5]. Natasa Hoic-Bozic et al. used a dedicated learning management system (LMS) called adaptive hypermedia courseware to combine face-to-face environment and online learning to realize blended learning [6]. The original intention of the third-type platform is not teaching; rather, they feature powerful functions and extensive applications, and once they are transformed for teaching, the representative platform is WeChat [7].

Related system design and development of blended learning are directly related to its quality. Designing a reasonable and effective learning system guarantees the blended learning effect. Terumi Miyazoea and Terry Anderson conducted an exploratory research on the application of three platforms, namely, forum, blog, and Wikipedia, for EFL blended learning courses in a university in Tokyo, Japan. Students held positive attitudes toward blended course design and online writing. Wikipedia was the most popular, followed by blog and forum. Qualitative text analysis of forum and Wikipedia writing revealed that students gained progress in distinguishing English writing styles. Interview script analysis expounded various advantages perceived by students in different activities. Changes due to blended course design were good for coping with challenges and were very interesting for students [8]. Xiaoshan Xie and Zulin Zhu analyzed related factors influencing blended teaching quality in institutions of higher learning through questionnaire survey and interview in their thesis "Influence Factor Analysis of Blended Teaching Quality in Institutions of Higher Learning." The other factors included teachers, students, teaching support system, teaching effect, and evaluation. They proposed concrete suggestions for effectively improving blended teaching quality, and they expected to adjust and optimize main factors influencing blended teaching quality to enhance the quality of blended teaching in higher education institutions [9].

Applied research of blended learning is the most intuitive method that embodies popularization and application status and verifies the blended learning effect. As for blended learning research in basic education, America has accumulated rich experience in K-12 blended learning. For instance, "Handbook of Research on K-12 Online and Blended Learning" published by Kathryn Kennedy expounded on the research status and development background of K-12 online and blended learning as well as the scope of currently used research methods [10]. Vo HM et al. analyzed the effects of blended learning on academic achievements of college students and verified that blended learning and STEM disciplined students had better learning performance than traditional classroom practice [11]. Chuanjun Feng believed that blended learning had many advantages, but blended teaching neglected teacher guidance and reduced teacher-student exchange time. Blended teaching emphasized student initiative and lowered teachers' supervising ability. In addition, blended teaching degraded teaching 
pertinence and reduced students' learning effect. Therefore, students who were used to traditional teaching pattern had a hard time to accept a new teaching method. Teachers accumulated a large quantity of traditional teaching experience and subsequently needed to re-learn to change their teaching style. School leaders had not attached enough importance to establish a complete blended teaching pattern [12]. Iuliana Dorobat put forward ERP training pattern based on blended learning framework, which could integrate with ERP system to provide more individualized training management of ERP, and was effective and cheap [13]. Gynther Karsten developed an adaptive MOOC design framework and used blended learning to supplement the MOOC format. The design framework consisted of a design model and a series of learning design principles, which could be used to design in-job courses for teachers' professional development. The framework was evaluated through $\alpha$ and $\beta$ tests, and the relationship between design principle and intent and between implementation and implementation design [14].

The remainder of this work is structured as follows. Section 3 expounds on WeChat-based teaching design by discussing teaching pattern, platform, and scheme design. The comparative teaching experiment and verifies the practical effect of WeChat-based blended learning. are reported in Section 4. Finally, the concluding remarks are provided in Section 5.

\section{WeChat-Based Teaching Design}

\subsection{Introduction to the WeChat platform}

The WeChat platform includes three aspects of connotation, personal and public accounts and third-party platform. When an ordinary user uses WeChat, he/she mainly logs in a personal account, namely, the WeChat personal account. The WeChat platform is of low use cost and free of charge, and a user only needs to connect to the network and pay the operator network fee. WeChat features low popularization cost and boasts of many users. The 2018 financial report data of Tencent showed that number of monthly active accounts of WeChat (Chinese and overseas version) reached 1.058 billion, and students did not need to download or install the app separately. WeChat, having low learning cost, is common mobile software. The background operation of a WeChat public account is not complicated with any online learning materials. The operation of the WeChat public platform is easy only if no high-difficulty WeChat third-party development is not involved.

WeChat platform has various functions. The personal and public accounts can already satisfy most teaching demands. Together with WeChat third parties with strong extensibility, the demand of blended learning can be satisfied. For instance, WeChat can cultivate students' exchange and expression abilities. Students can discuss about one problem with the teacher and classmates to promote transformation of implicit to explicit knowledge. Learning on WeChat is not restricted by time or space. Students can learn at any time and any place, synchronously or asynchronously read learning materials, and exchange and discuss ideas with other classmates. 
Network marketing course is selected in this study to carry out blended learning. Besides being an online platform of blended learning, WeChat platform is the primary network platform for enterprises to implement network marketing activities. Teachers teach network marketing course through WeChat platform. On the one hand, teachers carry out teaching activities through abundant WeChat functions. On the other hand, they help students to familiarize with the WeChat platform, improve their professional qualities, and cultivate their WeChat-based network marketing skills.

\subsection{Theories of blended learning}

Blended learning is not based on a particular learning theory but is a mixture of various learning theories. The development of blended learning needs the guidance of a variety of learning theories to adapt to the requirements of different learners and types of learning objectives, environments, and resources. The theories to guide blended learning should be diversified. Theories in blended learning research include constructivist, cognitive, humanistic learning theories, and others.

Constructivism learning theory: Constructivism learning theory is an important theoretical basis of blended learning. Constructivist learning theory holds that the world exists objectively, but the understanding of things is determined by each person. Different people have varied understandings of the same concept due to their diverse experiences. Learning aims to guide students to construct new from original experiences.

In blended learning, teachers not only deliver teaching contents and guide and inspire students but also provide various learning resources, create various learning environments, choose diversified learning methods and styles, and carry out diversified learning evaluation. With the help of teachers, students can construct the meaning and ability of relevant knowledge according to their experiences.

Cognitive learning theory: According to cognitive learning theory, learning is not a process of forming stimulus response connection under the domination of external environment, but a process of constructing cognitive structure inside the mind. Learning requires learners to organize and relate new information to existing knowledge in a meaningful way.

In blended learning, the implementation of teaching activities is in the traditional and online classrooms. Teachers use teaching media to develop and design rich learning resources, combine boring content with real life, and stimulate students' interest in knowledge exploration and learning. In blended learning, teachers pay attention to students' behavior and psychological changes through online learning platform. Hence, students have enough time to learn independently, internalize knowledge, and improve initiative and enthusiasm.

\subsection{Design pattern of WeChat-based blended learning}

Blended learning combines multiple learning theories, which address the requirements of diverse learners as well as learning objectives, environments, and resources. Theories include constructivism, cognitivism, humanistic, and others. Fig. 1 shows the 
design framework of a blended learning course. According to this framework, a blended learning course design work is divided into three phases, which are frontal analysis, activity and resource design, and teaching evaluation design.

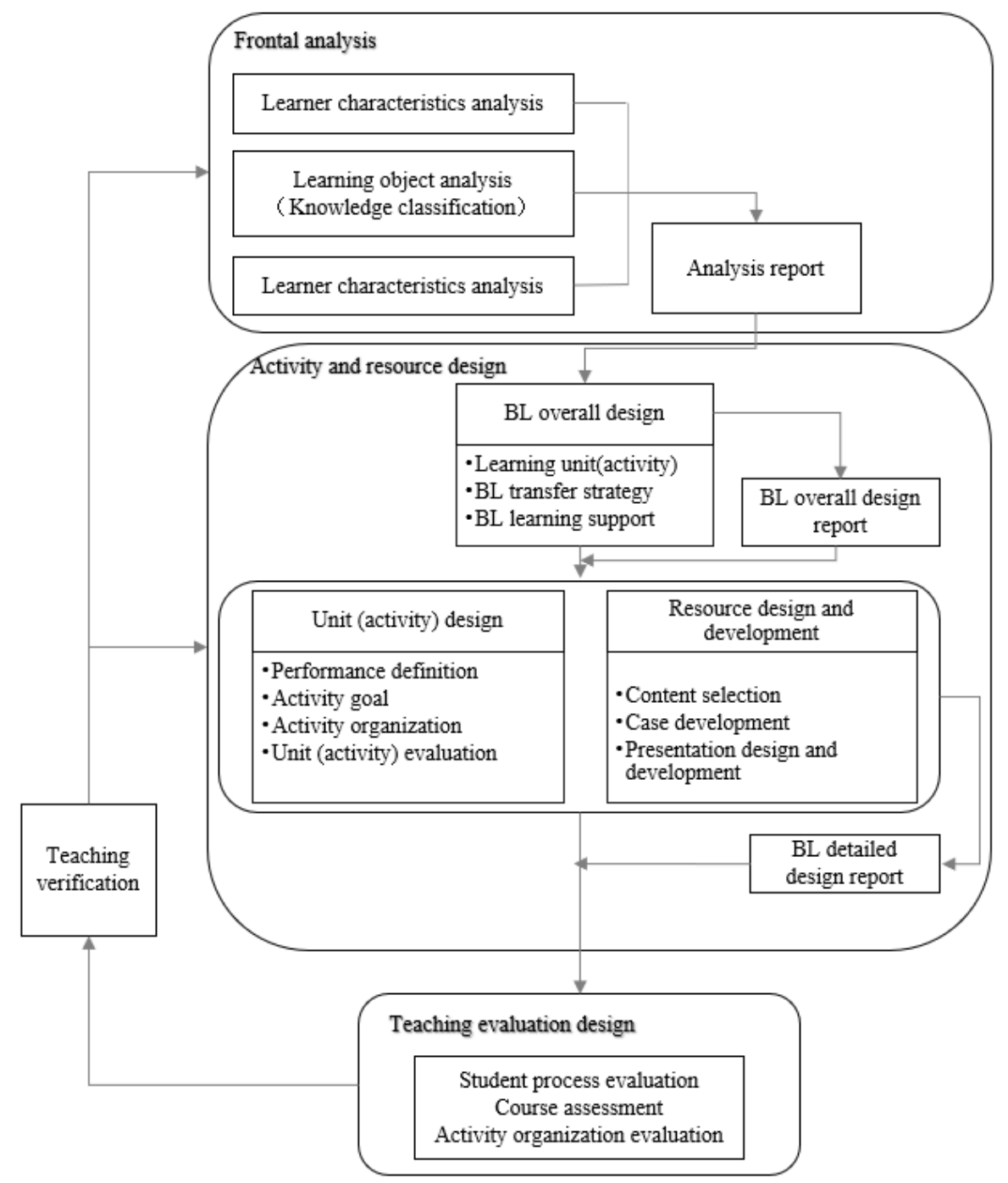

Fig. 1. Design framework of blended learning course

According to related theories of blended learning, the functions of the WeChat platform and features of network marketing course are combined. The WeChat-based blended learning pattern design of the network marketing course includes frontal analysis, activity and resource design, and teaching evaluation design, as shown in Fig. 2. The activity and resource design is the phase that can embody the features of 
blended learning most. Frontal analysis includes learner feature, learning content, and blended learning environmental. Teaching evaluation design includes evaluating student process, course assessment, and activity organization. Activity and resource design phase are divided into three parts, namely, pre-, in-, and after-classes. The preclass part refers to the preview before class and after-class part is the review under the support of WeChat platform. In-class part is implemented in two teaching environments. The traditional classroom implements theoretical teaching, and practical operation is carried out in the computer room, so theory is combined with practice. Using frontal analysis and teaching evaluation, teachers will adjust teaching strategies according to actual requirements, including but not limited to adjustment of teaching organization, operation specification, inventive means, and constraint rules.

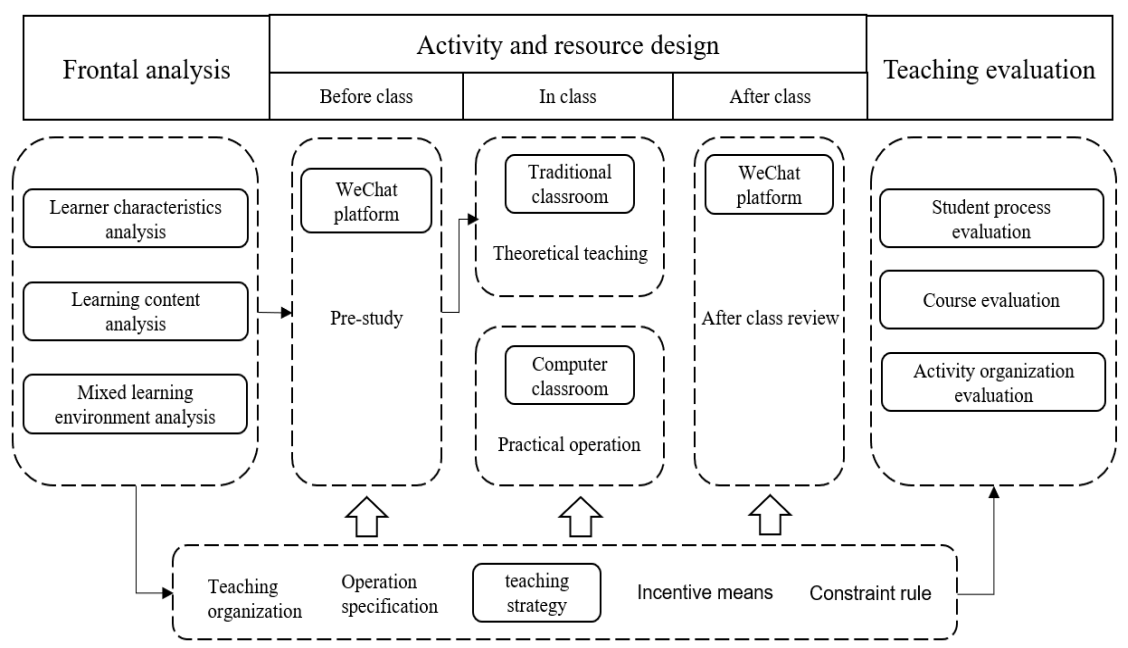

Fig. 2. WeChat-based blended learning pattern design

\subsection{Teaching scheme design of WeChat-based blended learning}

Teaching design is the bridge connecting learning theory and teaching practice and the foundation for successful teaching implementation. Under the guidance of blended learning theory, building the WeChat platform is as important as designing the teaching scheme, which jointly constitute the teaching design of blended learning.

Teaching contents: According to the current network marketing development status and students' conditions, the emphasis of practical teaching in this study is determined as basic knowledge of network marketing, network survey, WeChat marketing, Microblog marketing, short-video marketing, network marketing STP strategy and network marketing product, promotion, pricing, and channel strategies. Learning activities, namely, pre-, in-, and after-classes, are according to time sequence of learning activities. The learning environment in the in-class phase mainly includes the traditional classroom and computer room, and that of the pre and after phases is mainly conducted in the WeChat platform. 
Teaching activities: Learning activities in the in-class phase include two activity forms, namely, classroom teaching and practical operation, which are according to two different learning scenes, namely, traditional classroom and computer room. Classroom teaching is conducted in the traditional classroom. The teacher conducts verbal explanation-centered learning activity based on analysis and understanding according to teaching objectives, contents, and object. Classroom teaching steps include course import, scenario creation, course teaching, idea guidance, case demonstration, discussion organizing, class exercise, and summary and feedback. Practical operation is mainly implemented in the computer room. The teacher realizes the application of theoretical knowledge by giving assignments, cultivates students' manipulative ability and network marketing skills, and promotes their understanding of knowledge. Actual operation steps include assignment giving, operation demonstration, self-operation, question answering, assignment submission, and assignment evaluation.

Learning activities in the pre- and after-class phases belong to extracurricular learning activities. The learning environment is mainly the WeChat platform. According to a WeChat account, public account, and third-party module, extracurricular learning activities can be divided into three learning activity forms, which are exchange learning, autonomous learning, and training and inspection. Exchange learning can realize student-teacher and student-student exchange learning activities based on one-to-one chat and one-to-many group chat functions in the WeChat module. Autonomous learning conducts the preview before class, after-class review, and fragmental learning activity based on the functions of the public account module. Training and inspection conduct extracurricular training and course inspection, etc. based on a questionnaire survey, online test, and other functions of the third-party module.

Teaching evaluation: Teaching evaluation is the activity that realizes value judgment of the teaching process and serves teaching decision-making according to teaching objectives. In blended learning, teaching evaluation includes learning process, course assessment, and activity organization.

Learning process evaluation is relative to learning effect, but does not mean only paying attention to process but not result. Moreover, this type or evaluation pays attention to the process result of students' learning development, assesses students' learning mastery degree and level timely, improves teaching method, adjusts teaching activity, and guides the whole teaching activity. Learning activity evaluation in this study refers to evaluating students' learning status and learning activity performance on the WeChat platform. Qualitative or quantitative method is utilized and teaching methods, like self, mutual, and teacher evaluation, are combined to record objectively students' learning process and seek for the path to improve teaching activities.

Evaluation of course assessment refers to the paper test given to students after the learning activity. The paper test aims to check whether students have completed the learning objectives and the degree to which they master learning contents, conduct a quantitative analysis of results, and find problems and deficiencies in the teaching activity. Evaluation of activity organization means surveying students' learning attitude, satisfaction degree, and course feedback in WeChat-based blended learning after the learning activity. 


\section{Teaching Case and Effect}

\subsection{Teaching case}

WeChat marketing is in the content of Section Eight of Network Marketing (second edition). Through a detailed understanding of two cases of enterprise WeChat marketing, this section lets students deeply learn WeChat marketing-related knowledge and skills. As teaching materials are formed early, WeChat versions are updated very fast. Hence, cases in books already lag behind. Therefore, updating cases in teaching materials is necessary. Based on a combination of students' actual situation, existing software, and hardware facilities, WeChat marketing teaching firstly arranges students to experience a WeChat marketing activity. Subsequently, the lesson introduces knowledge contents, such as concept, form, common tool, and fan getting method of WeChat marketing. Finally, the lesson conducts computer operation to experience WeChat marketing.

The teaching objects are 2017 E-commerce class 2. Students in this class have depressing character and are not motivated enough in participating in the classroom. Given this situation, the emphasis should be laid on mobilizing students' initiatives in classroom teaching. WeChat marketing cases can be introduced to motivate their interests in WeChat marketing. All students have smartphones that have installed WeChat. Thus, students are very familiar with WeChat interfaces, functions, and operations, as well as a certain understanding of WeChat marketing.

Teaching knowledge contents includes basic concept and form, common tool, and fan-getting methods of WeChat marketing. Ability objectives include mastering use and propagation skills of WeChat public accounts. Case analysis, teaching, heuristic expository, and practical teaching methods are used in this course. Case analysis method presents the basic flow of WeChat marketing to students by introducing WeChat marketing cases. Expository method makes students rapidly understand the basic functions of WeChat public account through teaching. Heuristic teaching method guides students to exchange and think deeply by asking questions. After which, students summarize their previous learning and subsequently introduced to deeper understanding of WeChat marketing. Practical teaching method enables students to obtain perceptual cognition of WeChat use through actual operation, and in this way, students can preliminarily master basic operations of the WeChat public platform.

Course teaching is arranged according to the WeChat-based blended learning pattern design. First, the whole WeChat marketing course is divided into pre-, in-, and after-class phases, where pre- and after-class are online and in-class is offline. This teaching has four class hours, where the first two class hours are arranged in the traditional classroom and the remaining two are arranged in the computer room. Teaching arrangement is shown in Fig. 3. 


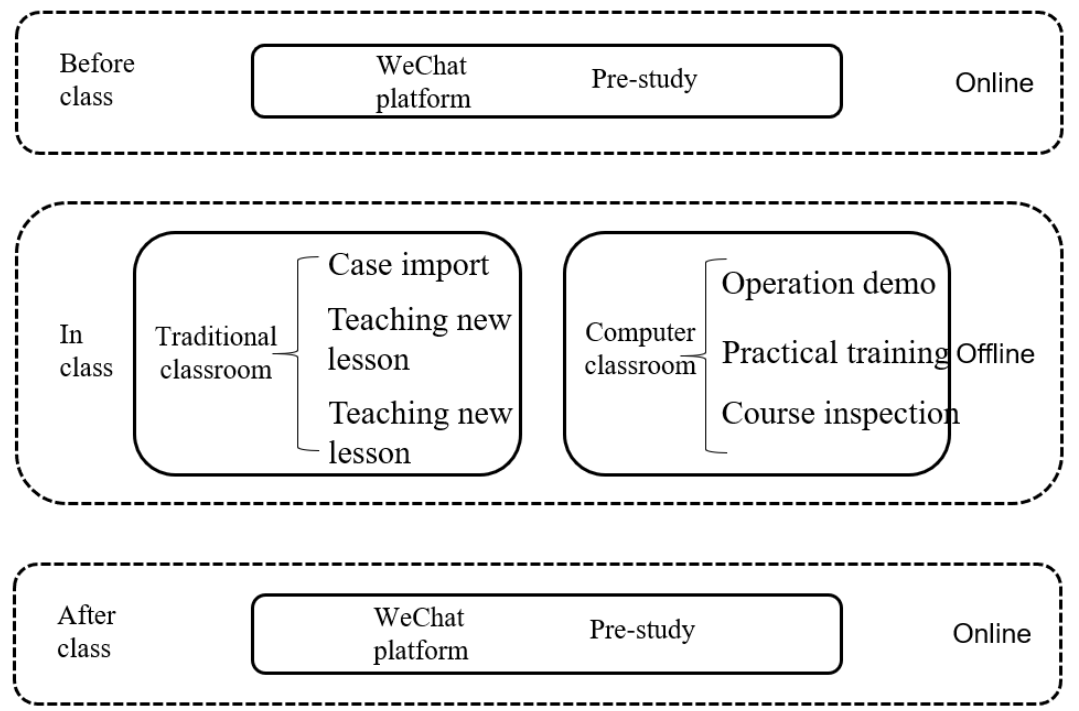

Fig. 3. Schematic diagram of teaching arrangement

\subsection{Teaching effect}

Experimental design: To verify blended learning effect in the network course, an experimental study lasting one semester was carried out in this study. Experimental objects were E-commerce classes 1 and 2 with 60 students. In class 1, 36 students adopted the traditional classroom teaching (control group) and in class 2, 32 students were subjected to teaching according to WeChat-based blended learning (experimental group).

Teaching activity of blended learning was taken as the experimental variable in the experimental group. Teaching activity was done according to the original traditional teaching mode. Teaching activity and course performance were the independent and dependent variables, respectively. Irrelevant variables were controlled, such as having the same teacher, pre- and post-experiment test papers, teaching material and content, and environment in the two classes. The experiment lasted 18 weeks with 4 class hours for each class every week. The experimental process is as follows:

Before the experiment test was carried out, frontal analysis was conducted within one week before the term began. The two experimental groups were determined. These groups were kept identical in learning performance, situation, etc.

Experimental teaching was implemented. Practical teaching based on blended learning was done in the experimental group. Teaching activity in the control group was conducted according to the original traditional teaching mode.

Post-experiment test was administered. After the course ended, two experimental groups were put under course evaluation, and final course performances were analyzed.

Experimental results were analyzed, and the practical experience was summarized. 
Pre-experiment test analysis: To obtain objective and comprehensive understanding of learning objects, a questionnaire survey method was administered to survey the experimental objects. A frontal analysis questionnaire was used to derive an understanding of the five dimensionalities, namely, personal information, information quality, learning motive and attitude, starting point and learning ability, and learning style and habit. Out of the 36 questionnaires given to the control class, 36 were recycled, and 23 questionnaires were given to the experimental class and 23 ones were recycled. After the survey data were summarized and tested, survey results were analyzed and compared. As shown in Table 1, the reliability analysis of Cronbach's alpha was carried out for the main items in the questionnaire, and the coefficient of Cronbach's alpha was 0.704 .

Table 1. Pretest questionnaire reliability

\begin{tabular}{|c|c|}
\hline Cronbach's Alpha & Number of items \\
\hline 0.704 & 13 \\
\hline
\end{tabular}

The experimental and control classes were two parallel classes with the same major. According to the school, the students were divided into the two classes according to their enrollment sequence and performance ranking. Teachers and course arrangement in the two classes were the same. Tables 2 and 3 show descriptive statistical analysis and independent sample T-test of the final performances of the two classes in the last semester, respectively.

Table 2. Description statistics of last semester final grade

\begin{tabular}{|l|c|c|c|c|c|}
\hline & Class & $\mathbf{N}$ & Average & Standard Deviation & Standard error mean \\
\hline \multirow{2}{*}{ Fraction } & 1.00 & 36 & 83.2528 & 4.81619 & 0.80270 \\
\cline { 2 - 6 } & 2.00 & 23 & 85.2130 & 3.07842 & 0.64189 \\
\hline
\end{tabular}

The average scores of the two classes in the last semester were 83.3 and 85.2 , respectively. Levene's test with homogeneity of variance was significant $(\mathrm{F}=4.660$, $\mathrm{p}=0.035<0.05)$, indicating that discrete conditions of average performances of the two classes in the last semester were obviously different. According to $t$ value and significance with variance not assumed, test results did not reach significant level, indicating that the two classes had no obvious difference $(T=1.907, p=0.062>0.05)$ in average performance in the last semester. Average scores of the two classes were not significantly different, meaning that the two classes basically had the same learning performance.

Table 3. Independent sample test of last semester final grade

\begin{tabular}{|c|l|c|c|c|c|c|c|c|}
\hline \multicolumn{2}{|c|}{} & \multicolumn{2}{|c|}{$\begin{array}{c}\text { Levene's variance } \\
\text { equal test }\end{array}$} & \multicolumn{4}{c|}{ T-test for whether the average is equal } \\
\cline { 3 - 9 } \multicolumn{2}{|c|}{} & $\boldsymbol{F}$ & Sig. & $\boldsymbol{T}$ & $\boldsymbol{d f}$ & $\begin{array}{c}\text { Sig. (Two- } \\
\text { tailed) }\end{array}$ & $\begin{array}{l}\text { Average } \\
\text { difference }\end{array}$ & Std. error \\
\hline \multirow{2}{*}{ Score } & Equal variance & 4.660 & 0.035 & -1.736 & 57 & 0.088 & -1.9603 & 1.1294 \\
\cline { 2 - 9 } & $\begin{array}{l}\text { No equal } \\
\text { variance }\end{array}$ & & & 1.907 & 56.996 & 0.062 & -1.9603 & 1.0278 \\
\hline
\end{tabular}


SPSS software was used to conduct the independent sample T-test of preexperiment questionnaire items in the experimental and control classes. Data in Table 4 showed that no obvious difference was detected in the independent sample T-test analysis of survey data of 13 questions in 4 aspects of information quality, learning motive and attitude, starting point and learning ability, and learning style and habit, in the control and experimental classes.

The experimental and control classes had no significant differences in average performance in the last semester. The test result was insignificant through the independent sample T-test of question data (except for multiple-choice questions) in the preexperiment questionnaire survey in the two classes. Therefore, the two classes had no significant difference in learning performance and pre-experiment test result, thus conforming to experimental conditions.

\section{Post-experiment test analysis}

Analysis of evaluation of course assessment: The final test had a time limit of $100 \mathrm{~min}$. Reviewed by the teaching and research office, the test paper was of standard format and met the requirements of the teaching program with moderate quantity of test questions and moderate difficulty level. Test questions, reference answers, and scoring criteria had no mistakes and the test questions were diverse.

Table 4. Independent sample T-test of pretest

\begin{tabular}{|c|c|c|c|c|c|c|c|}
\hline & \multicolumn{2}{|c|}{$\begin{array}{l}\text { Levene's vari- } \\
\text { ance equal test }\end{array}$} & \multicolumn{4}{|c|}{ T-test for whether the average is equal } \\
\hline & & $\boldsymbol{F}$ & Sig. & $T$ & $d f$ & $\begin{array}{l}\text { Sig. (Two- } \\
\text { tailed) }\end{array}$ & $\begin{array}{l}\text { Average } \\
\text { difference }\end{array}$ \\
\hline \multirow{2}{*}{ Internet time } & Equal variance & 0.124 & 0.726 & 0.688 & 57 & 0.494 & 0.226 \\
\hline & No equal variance & & & 0.702 & 49.955 & 0.486 & 0.226 \\
\hline \multirow{2}{*}{$\begin{array}{l}\text { Use of WeChat } \\
\text { function degree }\end{array}$} & Equal variance & 0.231 & 0.633 & -1.725 & 57 & 0.090 & -0.523 \\
\hline & No equal variance & & & -1.730 & 47.503 & 0.090 & -0.523 \\
\hline \multirow{2}{*}{$\begin{array}{l}\text { Information retrieval } \\
\text { capability }\end{array}$} & Equal variance & 1.045 & 0.311 & -0.975 & 57 & 0.334 & -0.225 \\
\hline & No equal variance & & & -0.943 & 41.891 & 0.351 & -0.225 \\
\hline \multirow{2}{*}{ Use computer level } & Equal variance & 2.259 & 0.138 & -0.129 & 57 & 0.898 & -0.028 \\
\hline & No equal variance & & & -0.141 & 56.889 & 0.888 & -0.028 \\
\hline \multirow{2}{*}{ Professional attitude } & Equal variance & 0.750 & 0.390 & 0.282 & 57 & 0.779 & 0.054 \\
\hline & No equal variance & & & 0.276 & 43.532 & 0.784 & 0.054 \\
\hline \multirow{2}{*}{$\begin{array}{l}\text { Attitude towards } \\
\text { learning }\end{array}$} & Equal variance & 0.005 & 0.946 & -0.830 & 57 & 0.410 & -0.229 \\
\hline & No equal variance & & & -0.859 & 52.154 & 0.394 & -0.229 \\
\hline \multirow{2}{*}{$\begin{array}{l}\text { Attitude towards } \\
\text { achievement }\end{array}$} & Equal variance & 2.624 & 0.111 & -1.127 & 57 & 0.265 & -0.297 \\
\hline & No equal variance & & & -1.098 & 42.976 & 0.278 & -0.297 \\
\hline \multirow{2}{*}{ View on the course } & Equal variance & 0.285 & 0.596 & -0.380 & 57 & 0.706 & -0.079 \\
\hline & No equal variance & & & -0.376 & 45.517 & 0.709 & -0.079 \\
\hline \multirow{2}{*}{$\begin{array}{l}\text { Online shopping } \\
\text { frequency }\end{array}$} & Equal variance & 0.103 & 0.749 & 0.493 & 57 & 0.624 & 0.155 \\
\hline & No equal variance & & & 0.497 & 48.293 & 0.621 & 0.155 \\
\hline \multirow{2}{*}{$\begin{array}{l}\text { Use WeChat fre- } \\
\text { quency }\end{array}$} & Equal variance & 0.616 & 0.436 & -0.011 & 57 & 0.992 & -0.002 \\
\hline & No equal variance & & & -0.010 & 38.578 & 0.992 & -0.002 \\
\hline \multirow{2}{*}{$\begin{array}{l}\text { Relevant course } \\
\text { learning }\end{array}$} & Equal variance & 0.025 & 0.874 & -10.246 & 57 & 0.218 & -0.408 \\
\hline & No equal variance & & & -10.236 & 45.762 & 0.223 & -0.408 \\
\hline \multirow{2}{*}{$\begin{array}{l}\text { Assessment of } \\
\text { learning ability }\end{array}$} & Equal variance & 0.406 & 0.527 & 0.094 & 57 & 0.926 & 0.024 \\
\hline & No equal variance & & & 0.091 & 42.715 & 0.928 & 0.024 \\
\hline \multirow{2}{*}{$\begin{array}{l}\text { Extracurricular } \\
\text { study time }\end{array}$} & Equal variance & 0.171 & 0.681 & -0.442 & 57 & 0.660 & -0.133 \\
\hline & No equal variance & & & -0.437 & 45.173 & 0.664 & -0.133 \\
\hline
\end{tabular}


As shown in Tables 5 and 6, the course performances of the two classes in this semester were 81.5 and 86.0 , respectively. Levene's test with homogeneity of variance was significant $(\mathrm{F}=0.532, \mathrm{p}=0.469>0.05)$, indicating that discrete conditions of average performances of the two classes in the last semester had obvious differences. According to the $t$ value and significance with equal variance assumed, the test result was significant, indicating obvious differences between the two classes in average performance in this semester $(\mathrm{T}=-2.168, \mathrm{p}=0.034<0.05)$, and average performance of the experimental class was higher than that of the control class.

Analysis of course satisfaction evaluation: After the course ended, a post-test questionnaire survey was conducted in the experimental and control classes. Students were assessed from four dimensionalities, namely, overall and teacher satisfaction evaluation, learning condition and attitude, learning process evaluation, and activity organization evaluation. According to Table 7, the coefficient of Cronbach's alpha was 0.890. From Table 8, the experimental class average course satisfaction evaluation indicators were greater than that in comparative classes.

Table 5. Descriptive statistical analysis of final exam score

\begin{tabular}{|l|c|c|c|c|c|}
\hline & Class & $\mathbf{N}$ & Average & Standard Deviation & Standard error mean \\
\hline \multirow{2}{*}{ Fraction } & 1.00 & 36 & 81.519 & 7.7202 & 1.2867 \\
\cline { 2 - 6 } & 2.00 & 23 & 86.078 & 8.1205 & 1.6932 \\
\hline
\end{tabular}

Table 6. Independent sample test of final exam score

\begin{tabular}{|c|c|c|c|c|c|c|c|c|}
\hline & & \multicolumn{2}{|c|}{$\begin{array}{c}\text { Levene's variance equal } \\
\text { test }\end{array}$} & \multicolumn{5}{|c|}{ T-test for whether the average is equal } \\
\hline & & $F$ & Sig. & $T$ & $d f$ & $\begin{array}{c}\text { Sig. (Two- } \\
\text { tailed) }\end{array}$ & $\begin{array}{c}\text { Average } \\
\text { difference }\end{array}$ & Std. error \\
\hline \multirow[b]{2}{*}{ Score } & Equal variance & 0.532 & 0.469 & -2.168 & 57 & 0.034 & -4.5588 & 2.1027 \\
\hline & \begin{tabular}{|l|l} 
No equal \\
variance
\end{tabular} & & & -2.144 & 45.258 & 0.037 & -4.5588 & 2.1266 \\
\hline
\end{tabular}

Table 7. Post-test questionnaire reliability

\begin{tabular}{|c|c|}
\hline Cronbach's Alpha & Number of items \\
\hline 0.890 & 12 \\
\hline
\end{tabular}

Table 8. Independent Sample T-test contrast table for post-test result from the experimental and control classes

\begin{tabular}{|l|l|c|c|c|c|c|c|}
\hline \multicolumn{2}{|c|}{} & \multicolumn{2}{|c|}{$\begin{array}{c}\text { Levene's variance } \\
\text { equal test }\end{array}$} & \multicolumn{3}{|c|}{ T-test for whether the average is equal } \\
\cline { 3 - 8 } & $\boldsymbol{F}$ & Sig. & $\boldsymbol{T}$ & $\boldsymbol{d f}$ & $\begin{array}{c}\text { Sig. (Two- } \\
\text { tailed) }\end{array}$ & $\begin{array}{c}\text { Average } \\
\text { difference }\end{array}$ \\
\hline $\begin{array}{l}\text { Overall } \\
\text { satisfaction }\end{array}$ & Equal variance & 6.264 & 00.015 & -2.542 & 57 & 0.014 & -0.6256 \\
\hline & No equal variance & & & -2.751 & 56.564 & 0.008 & -0.6256 \\
\hline $\begin{array}{l}\text { Self-study } \\
\text { satisfaction }\end{array}$ & Equal variance & 2.990 & 00.089 & -3.073 & 57 & 0.003 & -0.9094 \\
\hline $\begin{array}{l}\text { Class } \\
\text { teacher } \\
\text { satisfaction }\end{array}$ & No equal variance & & & -3.297 & 56.042 & 0.002 & -0.9094 \\
\cline { 2 - 8 } & Equal variance & 9.648 & 0.003 & -3.971 & 57 & 0.000 & -1.1763 \\
\hline
\end{tabular}




\begin{tabular}{|c|c|c|c|c|c|c|c|}
\hline \multirow{2}{*}{$\begin{array}{l}\text { Classroom } \\
\text { atmosphere } \\
\text { satisfaction }\end{array}$} & Equal variance & 0.011 & 0.915 & -4.285 & 57 & 0.000 & -1.1655 \\
\hline & No equal variance & & & -4.428 & 51.918 & 0.000 & -1.1655 \\
\hline \multirow{2}{*}{$\begin{array}{l}\text { Satisfaction } \\
\text { with the } \\
\text { way of } \\
\text { class }\end{array}$} & Equal variance & 2.129 & 0.150 & -4.856 & 57 & 0.000 & -1.2126 \\
\hline & No equal variance & & & -5.136 & 54.772 & 0.000 & -1.2126 \\
\hline \multirow{2}{*}{$\begin{array}{l}\text { Enthusiasm } \\
\text { in complet- } \\
\text { ing home- } \\
\text { work } \\
\end{array}$} & Equal variance & 7.312 & 0.009 & -2.997 & 57 & 0.004 & -0.7886 \\
\hline & No equal variance & & & -3.256 & 56.742 & 0.002 & -0.7886 \\
\hline \multirow{2}{*}{$\begin{array}{l}\text { Homework } \\
\text { satisfaction }\end{array}$} & Equal variance & 3.434 & 0.069 & -3.293 & 57 & 0.002 & -0.9396 \\
\hline & No equal variance & & & -3.599 & 56.926 & 0.001 & -0.9396 \\
\hline \multirow{2}{*}{$\begin{array}{l}\text { Content } \\
\text { mastery } \\
\text { degree }\end{array}$} & Equal variance & 2.077 & 0.155 & -3.467 & 57 & 0.001 & -0.8007 \\
\hline & No equal variance & & & -3.657 & 54.464 & 0.001 & -0.8007 \\
\hline \multirow{2}{*}{\begin{tabular}{|l} 
Learning \\
activity \\
satisfaction
\end{tabular}} & Equal variance & 1.302 & 0.259 & -3.662 & 57 & 0.001 & -0.9831 \\
\hline & No equal variance & & & -3.922 & 55.907 & 0.000 & -0.9831 \\
\hline \multirow{2}{*}{$\begin{array}{l}\text { Course } \\
\text { liking } \\
\text { degree }\end{array}$} & Equal variance & 1.299 & 0.259 & -3.973 & 57 & 0.000 & -1.0302 \\
\hline & No equal variance & & & -4.171 & 53.959 & 0.000 & -1.0302 \\
\hline \multirow{2}{*}{$\begin{array}{l}\text { Usefulness } \\
\text { degree }\end{array}$} & Equal variance & 4.984 & 0.030 & -3.223 & 57 & 0.002 & -0.8164 \\
\hline & No equal variance & & & -3.467 & 56.221 & 0.001 & -0.8164 \\
\hline
\end{tabular}

\section{Conclusion}

With the development of teaching informatization, utilizing additional information technologies in class is becoming an inevitable trend. Multiple information-based teaching modes are emerging, of which blended learning is a representative. The design of WeChat-based blended learning was theoretically analyzed and expounded by studying blended learning-related theories and methods. A WeChat-based blended learning pattern was proposed, a blended teaching design of network marketing course was applied, and the effectiveness of WeChat-based blended learning pattern was verified through a teaching experiment.

The WeChat-based blended learning pattern lengthens the extracurricular learning time of students. Students' extracurricular preview and review frequency through the WeChat platform is higher than through textbook. WeChat-based blended learning pattern features attractive learning materials for students. Learning materials provided to students based on WeChat platform are in diversified forms, including but not limited to video, audio, pictures, and test. Moreover, these materials attract more attention and interest from students than book knowledge of relatively single form. Under the traditional single teaching mode, students ask the teacher questions during classroom or breaktime. Under traditional teaching mode, initiative of students is weak, and they consult the teacher less often. However, under the blended learning pattern, the teacher communicates with students through WeChat group and private messaging, thus expanding communication modes and providing more opportunities. Although students' initiative is not enhanced too much in practice, it is somehow elevated relative to traditional teaching mode. Under the WeChat-based blended learning pattern, student-teacher communication is more frequent than that under the tradition- 
al teaching mode, and teaching evaluation is significantly higher than that in traditional teaching.

WeChat-based blended learning pattern gives full play to dominant advantages of teachers under traditional teaching mode. In addition, the proposed method embodies the dominant role of students, and equal importance is attached to teaching and learning in the practical teaching activity. WeChat-based blended learning pattern lengthens students' extracurricular learning time by using WeChat mobile learning method, which enhances students' learning initiative to a certain degree.

\section{Acknowledgement}

This work was supported in part by the 2016 Provincial Undergraduate Teaching Engineering Construction Program (program number: 2016JG5) of Guizhou Normal University, Innovation and Entrepreneurship Project of Guizhou Normal University, Major Education Reform Project of Guizhou Normal University in 2018 (Project Name: Innovation and Practice of E-commerce Talent Cultivation Mode with Deep Integration of Industry and Education in Guizhou province, China), and 2019 Provincial First-class Major in Marketing in Guizhou province, China.

\section{$7 \quad$ References}

[1] Zhu Zhiting, Meng Qi. Mix and Match: The Use of Different Learning Modes in Distance Education. China Distance Education, 2003, vol. 19, pp.30-34.

[2] Rovai A P, Jordan H. Blended Learning and Sense of Community: A Comparative Analysis with Traditional and Fully Online Graduate Courses. International Review of Research in Open \& Distance Learning, 2004, vol. 5(2), pp.53-62. https://doi.org/10.19173/irrodl. v5i2.192

[3] Carman, Jared M. Blended learning design: Five key ingredients. Retrieved August, 2002, vol. (18), pp.209.

[4] Wang Hong, Zhang Hu. Research on Blending Learning Based on Lanmo Cloud Class. Value Engineering, 2018, vol. (7), pp.252-253

[5] Kong Weihong, Gao Ruili. Design and practice research of hybrid learning based on Moodle. China Educational Technology, 2008, vol. (2), pp.80-83.

[6] Hoic-Bozic N, Mornar V, Boticki I . A Blended Learning Approach to Course Design and Implementation. IEEE Transactions on Education, 2009, vol. 52(1), pp.19-30. https://doi. org/10.1109/te.2007.914945

[7] Yuan Lei, Cheng Xiaohui, Zhangyanli. Hybrid learning research supported by WeChat-Take the course "basic photography techniques" for example. China Educational Technology, 2012, vol. (7), pp.128-132.

[8] Miyazoe T, Anderson T. Learning outcomes and students' perceptions of online writing: Simultaneous implementation of a forum, blog, and wiki in an EFL blended learning setting. System, 2010, vol. 38(2), pp.185-199. https://doi.org/10.1016/j.system.2010.03.006

[9] Xie Xiaoshan, Zhu Zulin. Factors Influencing Blended Teaching Quality at Higher Education Institutions. China Distance Education, 2012, vol. (10), pp.9-14.

[10] Kathryn Kennedy. Handbook of Research on K-12 Online and Blended Learning, 2014, pp.35-36. 
[11] Vo. H. M, Zhu C, Diep N A. The effect of blended learning on student performance at course-level in higher education: A meta-analysis. Studies in Educational Evaluation, 2017, vol. (53), pp.17-28. https://doi.org/10.1016/j.stueduc.2017.01.002

[12] Feng Chuanqi. Analysis on the problems and countermeasures of mixed teaching in colleges and universities. China Adult Education, 2017, vol. (21), pp.82-85.

[13] Iuliana Dorobat. Applying Blended Learning in ERP Training. Social Science Electronic Publishing, 2009, pp.121-122.

[14] Gynther Karsten. Design Framework for an Adaptive MOOC Enhanced by Blended Learning: Supplementary Training and Personalized Learning for Teacher Professional Development. Electronic Journal of e-Learning, 2016, vol. (14): pp.15-30.

\section{Authors}

Liang Zhang is an associate professor in School of economics and management, Guizhou Normal University, Guiyang 550001, China.

Yi Wu is a graduate student in School of economics and management, Guizhou Normal University, Guiyang 550001, China.

Xue Sheng Qian is a graduate student in School of economics and management, Guizhou Normal University, Guiyang 550001, China.

Ping Lv (corresponding author) is the dean and professor in School of Economics and Management, Guizhou Normal University, Guiyang 550001, China.

Xue Zhou is a doctoral candidate in University of Chicago, United States. Xue_Z@sina.com

Article submitted 2019-06-14. Resubmitted 2019-07-15. Final acceptance 2019-07-15. Final version published as submitted by the authors. 